\title{
Linking Infrastructure Across Africa and Asia: Practical Links Between SADC Corridors and the BRI Silk Road
}

\author{
Mbelwa Kairuki
}

During the opening ceremony of the 2018 FOCAC Summit in Beijing, President $\mathrm{Xi}$ Jinping stated that China was ready to implement the Belt and Road Initiative (BRI) as a new platform for international cooperation and China's contribution to the shared future of mankind. That statement, which was given on behalf of the People's Republic of China, was unanimously supported by the African leaders participating in the Summit. This provides the backdrop for the perspectives shared hereinafter on the important role of China as the emerging global economic prime mover, particularly in terms of the technological requirements and financial resources needed to fund the development initiatives of African countries in the context of the changing global political environment and global megatrends in the post-COVID-19 global economic reset.

China is currently poised to play a key role of responsibility in global leadership, being the only major economy to grow more than $2 \%$ in 2021 at a time when other major OECD economies continued stagnate. Further than that and going forward, China is on track to start implementing its 14th Five-Year Development Plan with clarity of purpose and strategic direction concerning its socio-economic objectives in the domestic arena. Projections for the rebound indicate steady growth that will exceed $4 \%$ year on year throughout the five-year plan implementation period.

Tanzania embraces the principles of FOCAC to underpin its multifaceted relationship with China and, in that regard, we hope that the bilateral economic cooperation between China and Tanzania can establish a solid foundation and to provide the scaffolding for building physical structures as strategic cooperation platforms for industry, logistics and trade development that dovetail into the regional market integration initiatives under the development context of East Africa Community (EAC) and the Southern African Development Community (SADC). Since China has already begun to implement the BRI as a new platform of international

M. Kairuki (凶)

Embassy of the United Republic of Tanzania to the People's Republic of China, Beijing, China

H. Wang and L. Miao (eds.), China and the World in a Changing Context,

China and Globalization, https://doi.org/10.1007/978-981-16-8086-1_19 


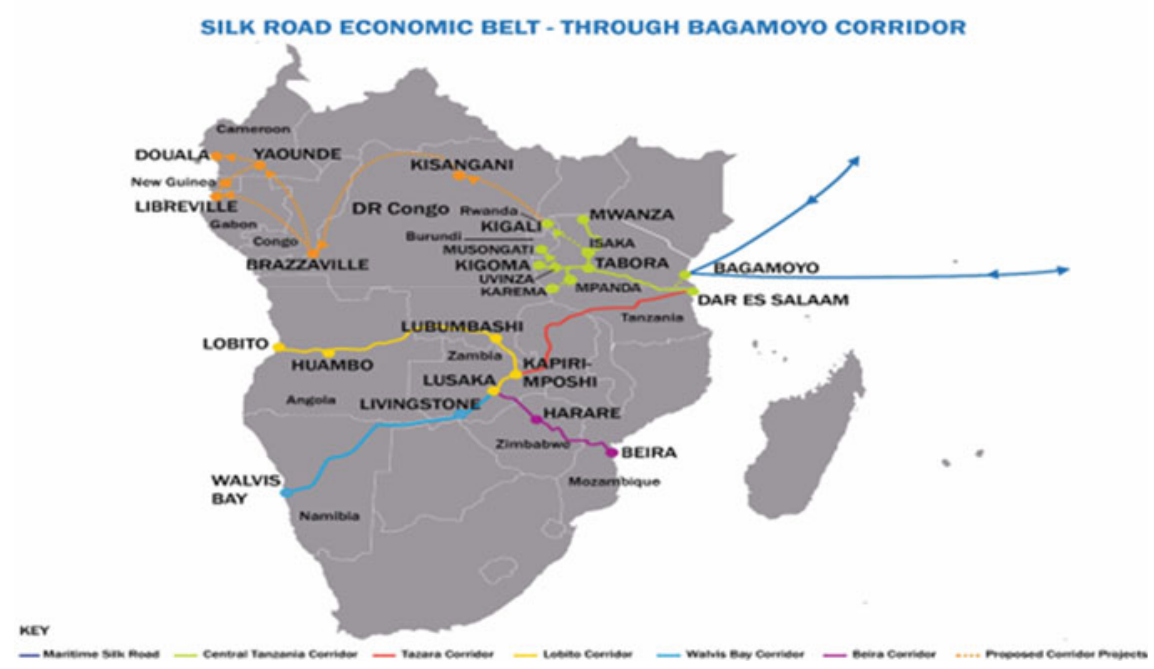

Fig. 1 Railway Corridors in Southern Africa

cooperation, Tanzania invites China to consider engagement to collaborate and participate specifically in the trans-border railway infrastructure development and services integration initiative which has been proposed by Angola and well received by Tanzania, calling for the development of seamless operation of the Benguela and TAZARA lines. The integrated railway line would become the backbone of transport infrastructure running through the regions endowed with the richest natural resources in Angola, Congo ("DRC"), Tanzania and Zambia with a westward-facing international gateway for trade via the Atlantic Ocean at Lobito and an eastwardfacing international gateway for trade via the Indian Ocean through Dar Es Salaam and Bagamoyo (Fig. 1).

The strategic concept and design of the SADC Development Corridors are similar to the China Belt and Road Initiative ("BRI"). The illustrative map above indicates how the BRI could be linked to four strategic SADC Development Corridors via the TAZARA Corridor. Efficacy of the SADC Development Corridor and SDI socio-economic transformation model is premised on synchronized investments in infrastructure for economic services and the exploitation of natural resources, linked to associated industry and logistics platforms. This holistic development model is designed to achieve comprehensive socio-economic transformation to promote SADC regional trade and enhance participation in world trade in value-added products via multi-modal transport terminals in related Development Corridors and SDIs. In that regard, railway transport connectivity is critical to providing the requisite carrying capacity to move large quantities of raw materials from primary production centres to industrial platforms and ultimately deliver intermediate and finished products to respective markets (Fig. 2). 


\section{SDISANDSADCREGIONALINTEGRATION}

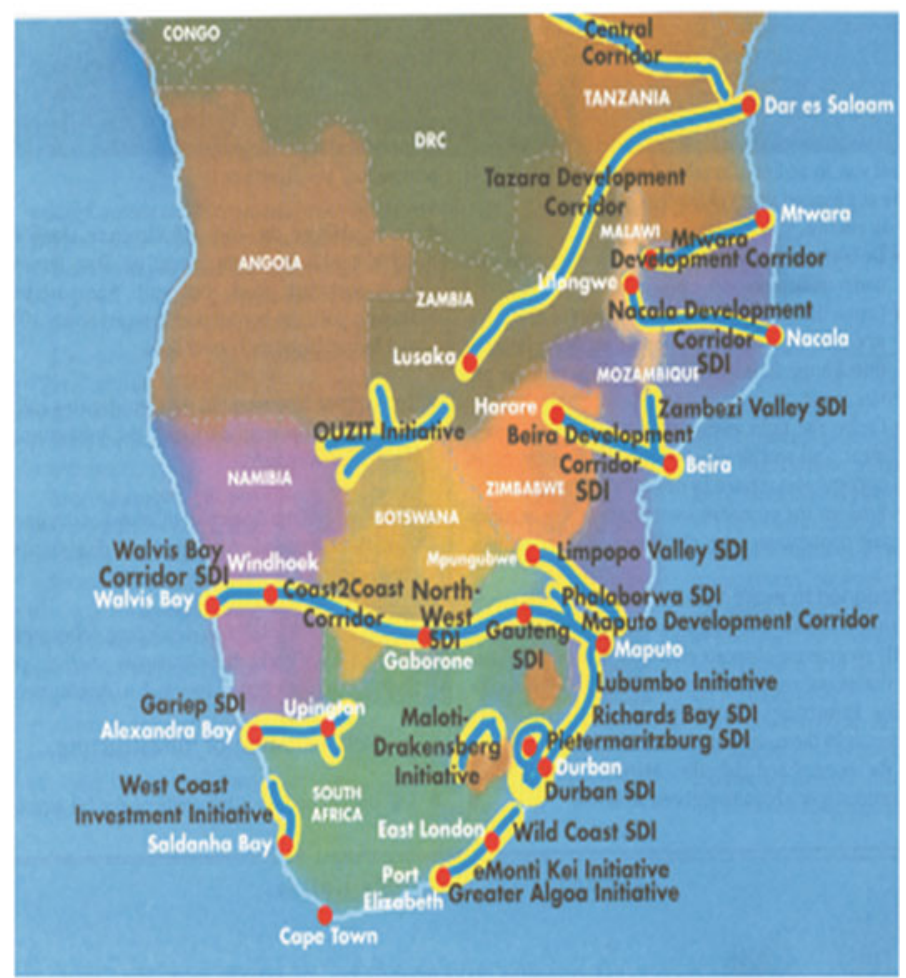

Fig. 2 Illustration of SADC Development Corridors and SDIs

The youthful demography of Sub-Saharan Africa will translate into a growing consumer market and labour pool that can be gainfully employed, allowing for relocation of part of the excess industrial production from China to the combined Benguela-TAZARA Corridor with a view to exploit the available abundant raw materials in the SADC region and transport finished goods or components more efficiently to global export markets via Lobito, Dar Es Salaam and Mtwara. The development of the Benguela-TAZARA Corridor will provide an impetus for the development of the Beira Corridor as well as the Walvis Bay Corridor from Lusaka as a hub for logistics services and traffic interchange (Fig. 3).

The active leading role of China in collaborating with international development initiatives through the BRI appears for now to be Eurocentric with a focus on reviving and modernizing the traditional Eurasian Silk Road. The conceptual Twenty-FirstCentury Maritime Silk Road, plying the Indian Ocean, skirts around the eastern seaboard of Africa and needles through Bab el-Mandeb into the Red Sea towards Mediterranean Africa. There is no roadway into the heartland of Sub-Sahara Africa where the TAZARA railway line made its first inroads, a lasting mark of the leadership 


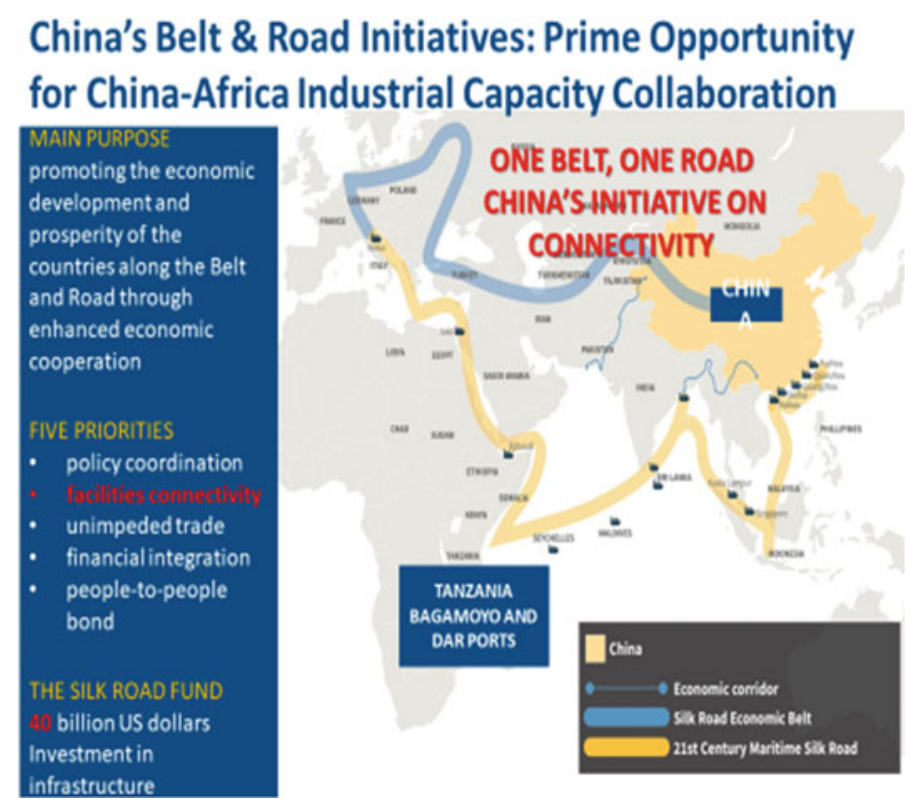

Fig. 3 Illustration of China BRI Configuration in Relation to Africa

and solidarity of the people of China, Tanzania and Zambia in both the armed struggle for liberation as well as the economic sphere. Now is an opportune time for the present leaders and people of China, Angola, the DRC, Tanzania and Zambia to rediscover that same spirit in economic solidarity and join hands to link the BRI with SADC Development Corridors and SDIs for our mutual benefit.

Clearly, there is an opportunity to create a symbiotic partnership between China's BRI and the SADC initiatives of trans-border regional "Development Corridors" and "Spatial Development Initiatives" (SDI) via the envisaged Twenty-First-Century Maritime Silk Road. In collaboration, China and participating SADC members could reach agreements to develop a regional implementation plan that links the TwentyFirst-Century Maritime Silk Road to the mutually agreed infrastructure projects and economic production programmes that have been approved under the Regional Indicative Strategic Development Plan (RISDP) of the SADC.

With regard to Sino-Tanzania relations, there is potential to develop manifold economic production projects in infrastructure, agriculture, industry and mining, which would have a strategic fit and catalytic impact in the development of the SADC coast-to-coast Benguela-TAZARA Corridor, as well as the development of supply chains for the EAC markets and ultimately feed the markets of the African Continental Free Trade Area ("ACFTA").

The rationale to develop multipurpose and multi-product Sino-Tanzania supply chain platforms in the form of industrial parks, as well as trade and logistics centres, is evident in considering the unique geolocation of Tanzania on the eastern seaboard 


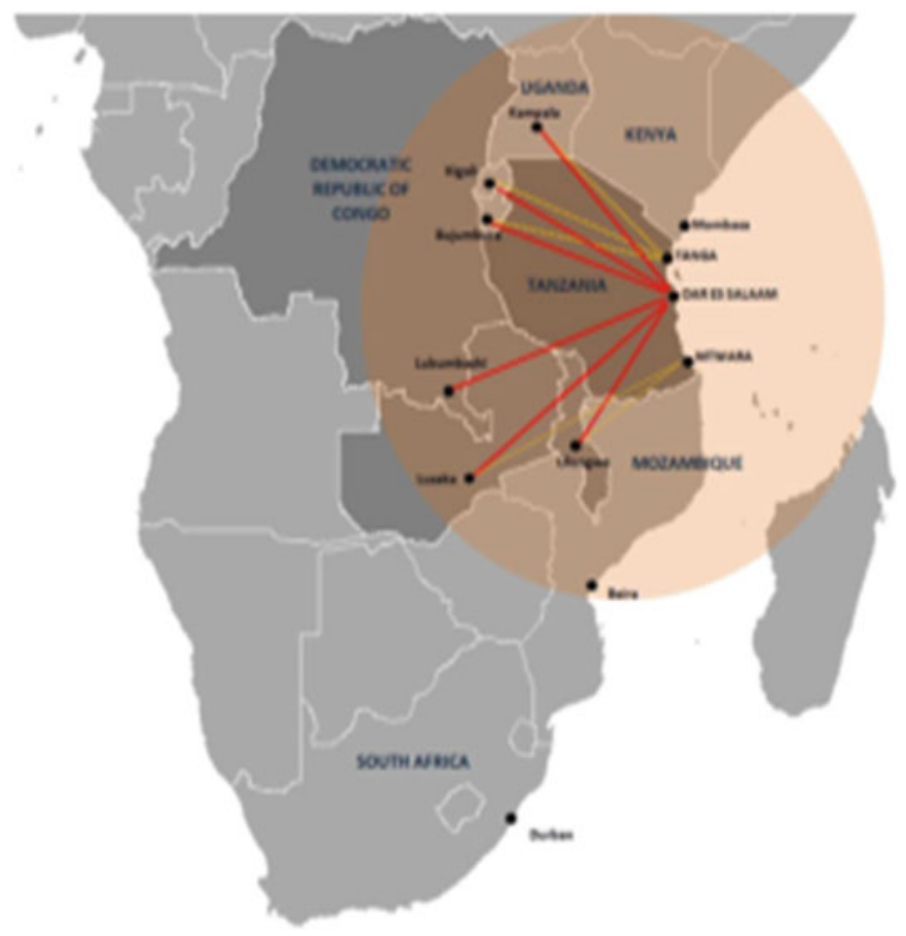

Fig. 4 Trade Impact Area of Tanzania as Bridge Economy Linking EAC and SADC Markets

of Sub-Saharan Africa, which faces the open trading highways to Asia and China via the waters of the Indian Ocean. One of the key industries that could be developed, with the potential for long-term growth within Africa and globally, is the production of electric power storage batteries that are manufactured using nickel, cobalt, vanadium and graphite. Tanzania could become one of the regional manufacturing and exporting centres for EVs, energy storage batteries and other equipment or components that will be designed to meet the requirements of the coming foreseeable industrial world, equipped with an ever-increasing number of machines, plants, equipment and transportation vehicles that will be powered by non-fossil fuel resources (Fig. 4).

In considering the matter of identifying specific areas of opportunities for immediate collaboration in the context of Sino-Tanzania economic relations with full political support, a fruitful approach would be first to synchronize areas of mutual interest with reference to China's 14th Five-Year Development Plan and the FiveYear Development Plan of Tanzania. Nevertheless, it can be safely surmised that our priority is food production to keep the cost of food low relative to industrial wages, because food inflation will always drive production costs to levels that can force industrial enterprises to close or migrate elsewhere.

Looking forward, the time is right to move from the vision of the potential of SADC Development Corridors and SDIs, into action within the auspices of FOCAC to link 
with the Twenty-First-Century Maritime Silk Road of China's BRI. A well-structured integration of these two initiatives will create opportunities to produce tangible and measurable outcomes in terms of investments in natural resource exploitation to meet the industrialization goals of the SADC, the need for infrastructure, the delivery of social services as well as trade development objectives that will be mutually beneficial.

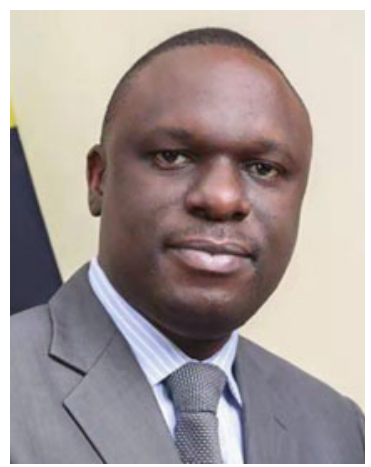

H.E. Mr. Mbelwa Kairuki is the ambassador of the United Republic of Tanzania to the People's Republic of China. He has been the ambassador of Tanzania to China since 2017. He was born in 1975 and graduated from the University of Hull, UK with MBA, LL.M in International Law. Mr. Kairuki served as the Advisor of United Nations Security Council Unit in the Ministry of Foreign Affairs, Personal Assistant to the President of the United Republic of Tanzania, Ambassador and Director of Asia and Australasia in the Ministry of Foreign Affairs, etc. $\mathrm{He}$ is a senior diplomat with rich experience in public sector administration and organization.

Open Access This chapter is licensed under the terms of the Creative Commons AttributionNonCommercial-NoDerivatives 4.0 International License (http://creativecommons.org/licenses/bync-nd/4.0/), which permits any noncommercial use, sharing, distribution and reproduction in any medium or format, as long as you give appropriate credit to the original author(s) and the source, provide a link to the Creative Commons license and indicate if you modified the licensed material. You do not have permission under this license to share adapted material derived from this chapter or parts of it.

The images or other third party material in this chapter are included in the chapter's Creative Commons license, unless indicated otherwise in a credit line to the material. If material is not included in the chapter's Creative Commons license and your intended use is not permitted by statutory regulation or exceeds the permitted use, you will need to obtain permission directly from the copyright holder.

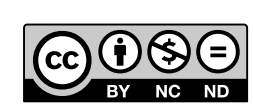

